\title{
Intersemiotic translation from fairy tale to sculpture: An exploration of secondary narrativity
}

\author{
Wenjing Li ${ }^{1}$, Jordan Zlatev ${ }^{2}$
}

\begin{abstract}
We present a cognitive semiotic case study of the narrative potential of the statue Den lille Havfrue ('the little mermaid') by Edvard Eriksen in Copenhagen. On the basis of theoretical analysis and a survey in which 20 European and 19 Chinese participants replied to questions concerning this statue we argue that it, and similar statues, may be considered as products of intersemiotic translation, but only if we dispense with any requirements of "equivalence" between source and target, since statues are necessarily semiotically highly reduced. While the source narratives constitute cases of primary narrativity, with narrations providing the audiences with stories, statues may partake only of secondary narrativity, where a prior story is needed for the statue to be understood as narration. In our study, this was reflected by correlations between reported prior knowledge and narrative (and possibly even non-narrative) interpretations of Den lille Havfrue. Finally, we relate the discussion to present-day cultural and political "settings", where many statues, including Den lille Havfrue, have become part of a global anti-racism narrative.
\end{abstract}

Keywords: primary narrativity; semiotic systems; cognitive semiotics; interpretation; narrative; Hans Christian Andersen; 'the little mermaid'; polysemiotic communication

\section{Introduction}

The famous little statue Den lille Havfrue ('the little mermaid'), perched on a rock in the harbour of Copenhagen, is currently considered to be one of the foremost symbols of Denmark. It was made by the sculptor Edvard Eriksen in 1913 as a result of a commission issued in 1909 by Carl Jacobsen, son of the founder of the Carlsberg Brewery. What provoked this commission was the deep impression left

1 English Faculty, School of International Studies, Zhengzhou University, No.100 Kexuedadao Road, Gaoxin District, Zhengzhou City, Henan Province, China; e-mail: xuewuhen1st@163.com. 2 Division for Cognitive Semiotics, Centre for Languages and Literature, Box 201, Lund University, 22100 Lund, Sweden; e-mail: jordan.zlatev@ling.lu.se. 
on Jacobsen by the Royal Danish Ballet's performance based on Hans Christian Andersen's famous fairy tale from 1837 (Bom 2012; Mortensen 2008).

Even given this minimal historical background we could surmise that the statue was a product of intersemiotic translation. Jakobson (1959: 233) defined this notion as "an interpretation of verbal signs by means of signs of nonverbal sign systems", while Sonesson (2014: 250) generalizes this to "transferring a meaning from one semiotic system to another", since neither the source nor the target of the process need be verbal. Still, even this definition is too narrow, since both the sculptor Eriksen as well as the commissioner Jacobsen were influenced not only by the verbal text of Andersen's fairy tale, but also by the above-mentioned ballet, as well as, presumably, by various drawings of the protagonist that had accompanied Andersen's text since its first publication, such as that shown in Fig. 1.

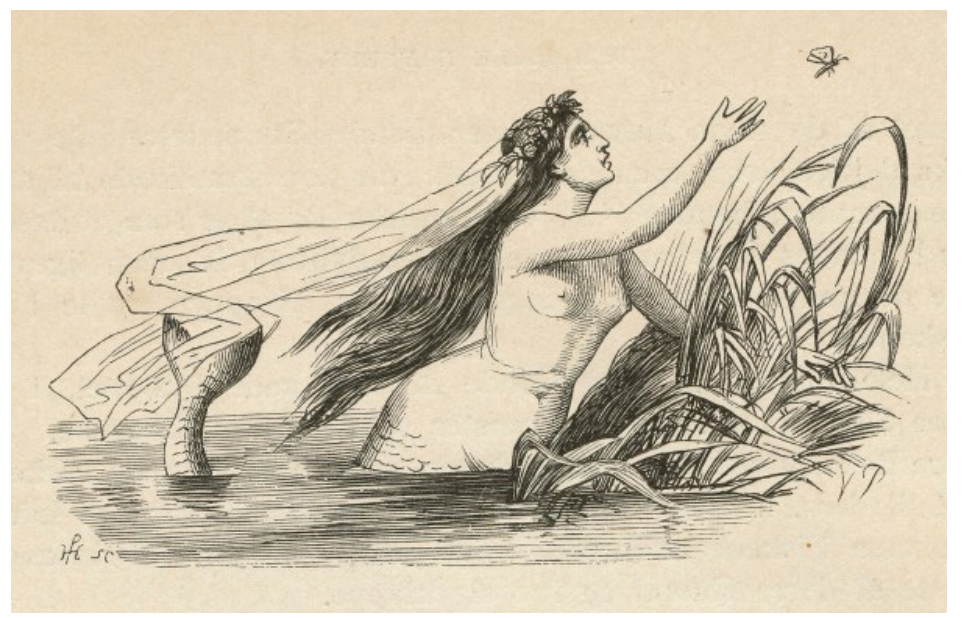

Figure 1. The Little Mermaid by Vilhelm Pedersen. Original illustration of H. C. Andersen's fairy tale with the same title, 1837 (source in public domain).

Hence, we could provide the following (tentative) definition: intersemiotic translation is the transfer of a source message expressed in one or more semiotic systems into a target message that at least in part involves different semiotic systems. A semiotic system consists of signs of a particular kind, and their characteristic interrelations and combinations (Zlatev 2019; Louhema et al. 2019). When more than one semiotic system is used, the message is polysemiotic. When this message constitutes a story, the composite of story and expression (see Section 2.2) constitutes a polysemiotic narrative: a narrative produced by the combination of two or more semiotic systems (Louhema et al. 2019; Stampoulidis 2019). 
The question arises how to characterize the outcome of the process of intersemiotic translation when the source is a rich polysemiotic narrative, and the target is not only monosemiotic, but highly semiotically reduced compared to the source, as is the case with a statue. Can we still regard the statue Den lille Havfrue as a narrative, without trivializing this notion? And should it even be regarded as the outcome of translation, given that we can hardly speak of "equivalence" between the "texts" (Nida 2004; Halliday 2001) of fairy tale and sculpture? Finally, to the extent that modern viewers of the statue do regard it as (part of) a narrative, are they not filtering it through other, more recent polysemiotic narratives, such as that of the Disney film from 1989, where the melancholy and tragic figure of the little mermaid transforms into the very different character of 'Ariel'? Finally, can we generalize aspects of the analysis to all statues, or even all sculptures (which do not need to be on public display like statues), as a particular kind of semiotic system? These are the questions we address in this article.

We do so with the help of cognitive semiotics, which combines concepts, theories and methods from linguistics, semiotics and cognitive science (Sonesson 2014; Zlatev 2015; Zlatev, Sonesson, Konderak 2016). One of the central features of cognitive semiotics is the conceptual-empirical loop, as shown in Fig. 2. Like traditional semiotics, cognitive semiotics investigates conceptually loaded theoretical questions such as those on the left. At the same time, like cognitive science and other more empirically oriented fields, it typically carries out specific empirical studies to help clarify these concepts, and in this way aims to provide as satisfactory answers to the original questions as possible.

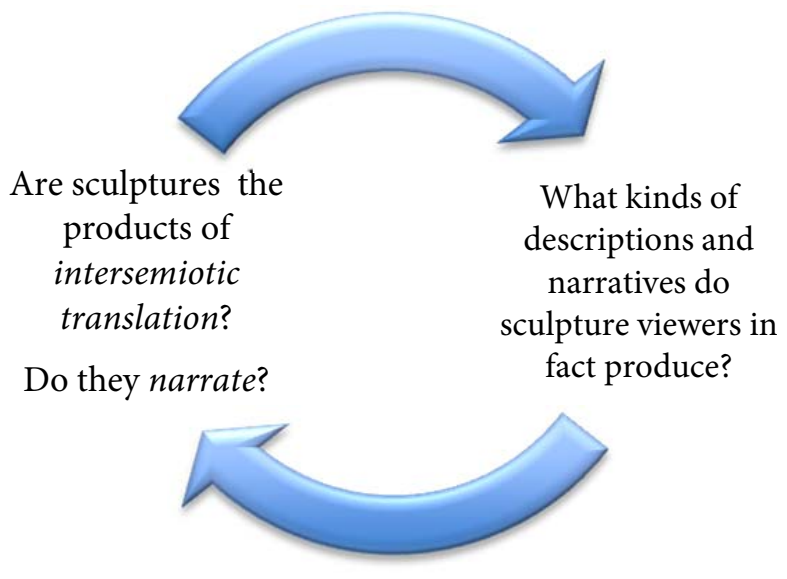

Figure 2. The conceptual-empirical loop of cognitive semiotics, as applied in the present study. 
We begin in Section 2 by reviewing relevant previous work concerning intersemiotic translation, including recent research on the popular topic of audio description, in which films are supplemented with verbal narrations for the sake of blind or visually impaired audiences (Holsanova 2016; Diget 2019). This process translates material from one kind of polysemiotic narrative (with moving images, speech, sounds and possibly music) into target narratives that are reduced in terms of sensory modality (from vision and hearing to only hearing), but still polysemiotic (including verbal commentary, the speech of the characters, sound effects, soundtrack). If we compare this with the case where the target is a statue, it becomes obvious how reduced the latter is. To explain how it can nevertheless narrate, we adopt a tripartite notion of narrative, consisting of the levels of fabula, story and narration, with roots in the tradition. Furthermore, we show the value of the concept of secondary narrativity (Stampoulidis 2019), which presupposes knowledge of the fabula and the story for the expression in question to function as narration. In contrast, in primary narrativity comprehension of the narration is a precondition for understanding the story and the fabula.

Given the extensive intermediality of contemporary culture where it has become a commonplace that "different media refer to and depend on one another, both explicitly and implicitly" (Jensen 2016: 1), there are multiple versions of "prior stories" which would prime the understanding of a statue in very different directions. With respect to Den lille Havfrue, these could be (a) Andersen's original fairy tale, (b) the Disney film or (c) some other of the countless adaptations of the fairy tale. ${ }^{3}$ Would not visitors who view the statue through different facets of the prism of $(\mathrm{a}-\mathrm{c})$ experience it quite differently, including its non-narrative aspects, such as the feelings it expresses?

To help answer such questions, we designed an empirical study based on interviews with visitors to the sculpture in Copenhagen, and conducted a pilot study with Chinese and European tourists in February 2020. The preliminary findings of this pilot study revealed that interpretations of the statue differed considerably between these two groups. Due to the ensuing Covid-19 pandemic, the study had to be put on hold, and instead we conducted a survey, as described in Section 3. In Section 4 we present the results of this study, and discuss these in Section 5. We conclude Section 5 by bringing the apex of the conceptualempirical loop back to questions concerning the applicability of the concepts of intersemiotic translation and narrative to (the phenomenon of) statues. ${ }^{4}$

3 Nearly 80 different adaptations are listed by Wikipedia at https://en.wikipedia.org/wiki/ List_of_The_Little_Mermaid_adaptations, accessed on 6 July 2020.

4 It is far from trivial to distinguish phenomena, or "the things themselves" in Husserl's famous dictum, from the concepts through which they are approached. While there are undoubtedly 


\section{Intersemiotic translation, narratives and statues}

As pointed out in the introduction, two main theoretical concepts form the backdrop for our study: intersemiotic translation and narrative. In this section, we provide some theoretical background to each, before addressing the narrative potentials of statues.

\subsection{Intersemiotic translation}

The term 'intersemiotic translation' introduced by Jakobson (1959) has been influential, but it has outgrown the narrow definition of "an interpretation of verbal signs by means of signs of nonverbal sign systems" (Jakobson 1959: 233). For example, Queiroz and Atã (2019: 301) suggest a much wider scope for intersemiotic translation in both producing and transferring meaning "in several semiotic phenomena, including literature, cinema, comics, poetry, dance, music, theatre, sculpture, painting, video, and so on. In this sense, the concept bears similarities to others like adaptation, ekphrasis, and transmediation". This take is certainly broad, but it does not help explain the nature of the transference process, as there are clearly important differences between, for example, transferring a message from literature to cinema, and from music to dance.

Sonesson's (2014) approach in analysing the concept is more informative, pointing out that intersemiotic translation (or 'transposition') "involves the transference of content from one kind of semiotic medium to another, such as illustrating a story with a picture or making a film out of a novel" (Sonesson 2014: 266). Between different "semiotic media" (a concept which Sonesson does not define), there is likely to be an "informational discrepancy". So, for example, when Shakespeare's play Macbeth is translated/transposed into specific theatrical performances and films, the way the character Macbeth, as well as all other personae in the play, is represented "depends on an innumerable series of choices on many different dimensions: kind of crown, shape of head, shape of nose, cheek contours, color of eyes, kind of beard, etc." (Sonesson 2014: 271).

Sonesson (2014: 272; our emphasis, W. L., J. Z). defines translation in general, and intersemiotic translation in particular, as "a double act of communication that has to take into account the sending and receiving instances of both acts

phenomena involved in the cases of narrative, and intersemiotic translation, these are so complex and multifaceted, that they have been approached through a number of different, and even conflicting, concepts. Our contributions in this respect are not claimed to lie in exhaustive analysis of the phenomena themselves, but of particular concepts of them, which we find to be fruitful. We thank the editor of the journal for prompting us to make this explication of the relation between phenomena and concepts. 
involved". This means that the translator has to consider (a) the author and their intentions, (what we may call) the knowledge base of the original audience for the author's message, and (b) the knowledge base of the target audience, and adapt the message in such a way that allows the target audience to receive as much of the original message as possible. Such translation can be deemed optimal. This is reminiscent of the famous definition of dynamic equivalence within translation studies, which is often stated as a goal in translation, at least in the context of interlingual translation:

Dynamic equivalence is therefore to be defined in terms of the degree to which the receptors of the message in the receptor language respond to it in substantially the same manner as the receptors in the source language. (Nida, Taber 2004: 24)

Sonesson's characterization of optimal translation is, however, more realistic, as there will always be "informational discrepancy" between the source and the target semiotic systems in the context of intersemiotic translation, and it cannot be expected that the audience of a message expressed in language would do so "in substantially the same manner" as those who view pictorial illustrations of this message. The best one can hope to achieve is some kind of compromise, with "enough" of the original message translated, and relying on the strengths of the target semiotic system to compensate for what has been lost in translation.

Another complication arises when the targets of intersemiotic translation are realized through complex combinations of multiple semiotic systems, as in theatre, opera and film. In these cases, many workers join in the process, including the director, the producer, the stage designer, and the costume designer. These work jointly to produce a specific rendition of, for example, Macbeth on stage. Unlike the (usually) individual translator of the common case of translating a text from one language to another, here it is hard to say who exactly the translator is. We could perhaps say that we have a "distributed translator", with the director often playing a dominant but non-exhaustive role, while specialists focus on specific media: the painter on the sets, the costume designer on the clothes, the composer on the musical score, etc.

A type of intersemiotic translation that is more reminiscent of the classic case where a single translator has to make the essential decisions on what is to be translated and how this is to be done through language, lies in audio description (see, e.g. Holsanova 2016) as films are supplemented with verbal narrations for the sake of blind or visually impaired audiences. This is an important field in which practice has come much further than theory. In this context, the role of a single audio-describer is crucial, as he or she has to perform, often for a 
live audience, a translation process from a message that is polysemiotic (with moving images, speech, sounds and possibly music) into a message that is also polysemiotic, but is reduced in terms of sensory modalities. This is shown in Fig. 3, based on Diget (2019), who analyses the practice with the help of cognitive semiotics. In audio description, we can clearly see a process of semiotic and sensory reduction, as verbal commentary has to substitute for the meaning given by depiction and gesture, and all relevant information from the visual modality needs to be provided through sound. Yet, at least in terms of semiotic systems, the scope of reduction is limited since language remains a key part of the target message.

\begin{tabular}{|c|c|c|}
\hline Medium & Semiotic systems & $\begin{array}{c}\text { Sensory } \\
\text { modalities }\end{array}$ \\
\hline Film & $\begin{array}{c}\text { Language (in speech and text), } \\
\text { depiction, gesture, music }\end{array}$ & Visual, auditory \\
\hline Audio description & Language, sounds, music & Auditory \\
\hline
\end{tabular}

Figure 3. Intersemiotic translation from film to audio description, adapted from Diget (2019: 22).

A stronger form of reduction in intersemiotic translation has been discussed by Bennett (2007), who examines three different ballet versions of Romeo and Juliet, all based upon Shakespeare's play and Prokofiev's musical score. Bennett (2007: 138) concludes that:

[...] most ballets, which generally derive their aesthetic structure and narrative content from some preceding text, may legitimately be considered as examples of intersemiotic translation. Indeed, many classical ballets are based upon not one but two prior texts - a musical score, which largely determines the form and emotional thrust of the choreography, and a canonical or popular work of literature of which the score is itself a 'translation'; hence there is a dual transfer involved.

A number of constraints investigated by Bennett result in discrepancies between the three ballet versions of Romeo and Juliet. ${ }^{5}$ For our purposes, however, what the three translations have in common is more important: all involve an

5 Bennett (2007) discusses the following five "constraints": Originals, Code, Poetics, Patronage and Universe of Discourse. 
intersemiotic translation from a polysemiotic source (verbal text, musical score) to a polysemiotic target (dance, scenography, musical score), but differently from the audio description, language is absent in the target. Unsurprisingly, ballet viewers are asked to read the "plot" of the ballet before viewing it, since unless they are familiar with the story (from Shakespeare's text or otherwise), they are likely to arrive at very different interpretations of what they see on stage in terms of narrative comprehension.

This brings us to the key concept of 'narrative', and to the question if such extremely reduced intersemiotic translations like Den lille Havfrue can be regarded as narrations, which we discuss below.

\subsection{Defining 'narrative'}

The phenomenon of narrative is central in many fields, including literature, philosophy, psychology and semiotics. As a consequence, the concepts behind the term 'narrative' vary considerably (e.g. Louhema et al. 2019; Diget 2019). Within the interdisciplinary field of narratology, a term introduced by Todorov (1969), a well-known minimal definition of narrative is that proposed by Prince (2008: 19): "the logically consistent representation of at least two asynchronous events that do not presuppose or imply each other". This, however, is much too general, as it does not say anything about what defines "a logically consistent representation", and it is doubtful if even the most minimal of stories can concern only two events. We can, for example, note that Caesar's phrase "Veni, vidi, vici" ('I came, I saw, I conquered'), famous for its laconicism, includes three events, and by skipping any one of these ('I came, I saw'; 'I came, I conquered'; 'I saw, I conquered'), the minimal narrative quality of the "text" seems to be compromised.

Ever since Aristotle's Treatise on Poetry (1812[335 BC]), most narratologists have emphasized that a narrative must constitute a coherent representation of a sequence of events, organized in some version of the schema: Beginning-MiddleEnd. For example, the influential Encyclopedia of Semiotics (Budniakiewicz 1998: 437) states:

As an ordered sequence of events that "unfolds" in the course of a reading, a narrative has temporal and chronological dimensions. Yet these events must be held together by a single image if one is to be aware of temporal progression at all. The unity established through the organization of "temporal wholes" derives from the organization of successive events in such a way that they form a unified sequence of change in which there is a beginning, middle, and end. 
Orthogonal to this tripartite temporal structure, there are three "vertical" levels of every narrative (see, e.g. Genette 1980; Branigan 1992; Allen 2013). On the lowest layer, there is the fabula, the chronologically and causally ordered sequence of events. One layer higher, these events are organized in a story, which does not need to follow the chronological order. For example, the minimal fabula communicated by Caesar in the famous example given above, could be organized as the stylistically less memorable: "I won, after I came and I saw". On the highest layer, the story needs to be expressed (narrated), and the semiotic systems of language, pictures and gestures can all be used as vehicles for narratives (Prince 1982). Thus, the term 'narrative' is best preserved for the whole three-layer structure shown in Fig. 4 :

\begin{tabular}{c} 
Narration: \\
The "telling" of the story in one or more semiotic systems \\
\hline Story: \\
$\begin{array}{c}\text { Organizing the fabula in a particular way, with (at least) Beginning, Middle and End, } \\
\text { albeit not always in this order }\end{array}$ \\
\hline Fabula: \\
A logically and chronologically ordered sequence of events \\
\hline
\end{tabular}

Figure 4. The three layers of a composite concept of 'narrative'.

Such a three-level concept of narrative was also proposed by Bal (1997: 5), who used the terms narrative text, story and fabula, respectively:

[A] narrative text is a text in which an agent or subject conveys to an addressee ("tells" the reader, viewer, or listener) a story in a medium, such as language, imagery, sound, buildings, or a combination thereof. A story is the content of that text and produces a particular manifestation, inflection, and "colouring" of a fabula. A fabula is a series of logically and chronologically related events that are caused or experienced by actors. (our emphasis, W. L., J. Z.)

Building on this tradition, Stampoulidis (2019) asks the question whether works of Greek street art such as that in Fig. 5 constitute narratives. His conclusion is that they do not - if this requires the capacity to understand the story (and fabula) ${ }^{6}$ on

6 The distinction is not relevant for single pictures or statues, so we will use 'story' for both in what follows. 
the basis of the narration itself, as is common in typical narrative texts in language or some other dynamic semiotic system. Stampoulidis (2019:34) refers to this as primary narrativity, "understanding the narrative by going from narration to the underlying story, under the constraints of the frame-setting", and proposes that static pictures in general lack this capacity. What single static pictures such as that in Fig. 5 have is the potential for secondary narrativity: "understanding the narrative by going from underlying story to the narration, under the constraints of the frame-setting" (Stampoulidis 2019: 34). ${ }^{7}$ This means that if the audience already has access to one or more "underlying stories" - in this case from Greece's mythologized history - then they can understand the painting as a particular kind of narration, and the whole as a narrative, in this and similar cases concerning the recurrent struggle between Greeks and "foreign invaders".

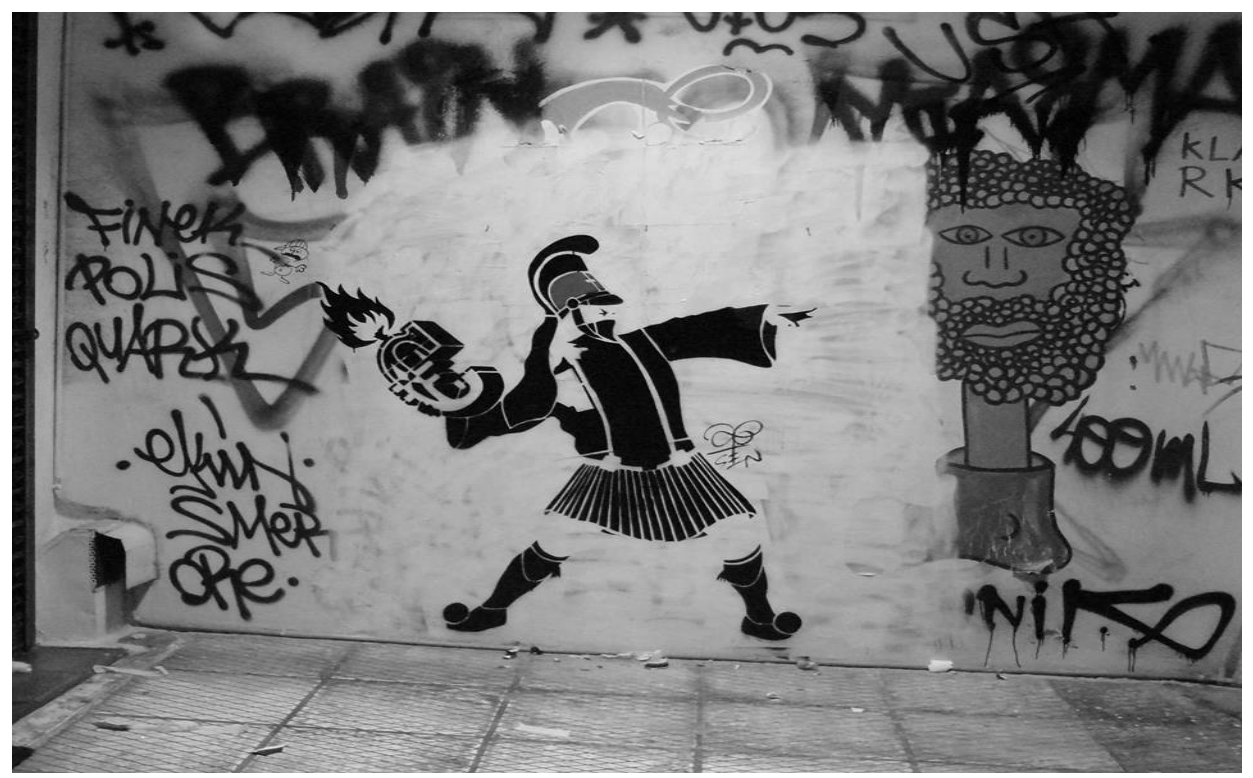

Figure 5. Greek guard with €-Molotov cocktail in Monastiraki, Athens, 2012. From Stampoulidis 2019; used with the permission of the author.

7 By 'frame-setting', Stampoulidis does not mean a separate narrative layer as in Fig. 6, but rather the relevant background knowledge that both the author and the audience can be expected to have access to. It corresponds to what we called 'knowledge base' in the introduction, and to a subset of Umberto Eco's notion of 'encyclopaedia' (Desogus 2012), interpreted in more cognitive-experiential terms. 
The concept of secondary narrativity is very productive and can help analyse the narrative potential not only of (street art) pictures, but also of many other non-verbal narrations. For example, this helps explain the difference between the products of intersemiotic translation in the case of audio description on the one hand, and ballet on the other hand, as discussed above. In the former case, the target message, even though reduced in terms of semiotic systems and sensory modalities, can still realize primary narrativity: the audience can understand the story on the basis of the narration. In the case of the ballet, however, the audience would need to be familiar with the underlying story to be able to (fully) understand the ballet performance as a narration, which implies secondary narrativity. As we will see below, this is even more the case with intersemiotic translation into statues such as Den lille Havfrue as targets.

\subsection{Sculptures as narrations}

The narrative potential of sculpture is often mentioned in the literature, but is generally recognized to be limited in comparison with other semiotic systems. For example, Pier (2008: 109) states that many sculptures display some, but not all, "elements of narrative". Without using the term, he acknowledges what we described as secondary narrativity: sculptures cannot narrate independently, but could perhaps activate background stories, and narrate with their help.

Wolf is somewhat more optimistic, and proposes that "sculptures such as 'Laokoon' can be 'read' as narratives" (Wolf 2011: 507). This is because sculptures often have "visible clues concerning the causes of the bodily motions and psychic 'e-motions' represented there" (Wolf 2011: 508). Wolf refers to Lessing's famous notion of the pregnant moment of an action: the temporal phase of the action that allows us to imagine the whole action, and possibly also its causes and consequences (see, e.g. Sonesson 1997). On this basis, Wolf (2011: 510) argues that if a sculptor has managed to represent this moment successfully, the statute could to some degree narrate on its own, "for the imaginary continuation of action backward and forward in time and generally for narrativization to occur, a knowledge of the textual background of the represented story is not indispensable" (Wolf 2011: 510). In other words, this implies that statues could possess some degree of primary narrativity. This appears similar to the argument offered by Sonesson (1997: 247) that (primary) narrativity is possible for some single "pictures with implied specific temporality: a single, static picture, which lacks multi-phasicality, but is recognizable as picturing an event taken from a wellknown or prototypical sequence of actions". 
Yet this is doubtful, since what such a single "pregnant moment" represented by a picture or statue would be able to communicate without the audience's knowledge of a prior story would probably be only immediately preceding actions and consequences. For example, the picture in Fig. 5 may indeed "narrate" that the "euro-bomb" will be thrown at someone and that the agent has picked it up before that, but, to use the words of Sonesson, such a "prototypical sequence of actions" is poor material for narratives, precisely because the sequence is predictable. To recall, the classic definition by Prince (see Section 2.2) stated that the represented events should "not presuppose or imply each other", and the events preceding and following "pregnant moments" are very much such presuppositions and implications, albeit not in the strictly logical sense of these terms, given that they are defeasible: the Greek fighter may or may not have lit the fuse to the bob, he may or may not fail to throw it at the enemy etc. On this basis we may conclude, at least preliminarily, that statutes can partake of secondary, but not of primary, narrativity. Indeed, even Wolf (2011: 510) points out that "the narrativization of sculpture $[. .$.$] may considerably depend on an intermedial reference to a verbal$ story".

In sum, sculptures can indeed be considered the outcome of intersemiotic translation from verbal texts, including fairy tales, under the conditions that (a) we dispense with notions such as (dynamic) equivalence, and treat the transduction from fairy-tale to sculpture as a form of strongly reduced intersemiotic translation, in which (b) the target lacks the capacity for primary narrativity, and has only secondary narrativity.

In the spirit of cognitive semiotics, we would wish both to validate and further explicate this conclusion with an empirical study. If the narrativity of a sculpture like Den lille Havfrue is indeed only secondary, its viewers should be completely dependent on prior stories concerning this fictional character when asked to "tell the story" about it. Given that there are at least two quite different prior stories likely to be known by a modern audience: Andersen's original fairy tale, and the Disney movie, the former with a tragic ending, and the latter with a happy one, viewers' narrative interpretations of the statue are likely to be framed quite differently, depending on which prior story is adopted. Further, such differences in the narrative background could perhaps influence even the interpretation of non-narrative aspects of the statue, such as the emotions expressed by its posture and facial features. Finally, we would also like to know if audiences from cultural backgrounds with considerable differences would be likely to arrive at different narrative and non-narrative interpretations, regardless of the prior story that served as their backdrop for the understanding. In the following three sections, we describe a study addressing precisely these questions. 


\section{Designing the study}

Our original intention was to conduct structured interviews with tourists visiting Den lille Havfrue in Copenhagen, interviewing Chinese and Western visitors. The aim was first to obtain answers on how visitors experience the emotions expressed by the statue, then to ask them to narrate briefly the story about this character, and finally to ask them about the source of their knowledge: the fairy tale, the movie(s), some other source, or perhaps none, and if their story was their own invention. A pilot study suggested that many Chinese visitors appeared "disappointed", as the statue was not what they had imagined. Many also appeared not to know Andersen's original fairy tale, which could explain why they were surprised by the melancholy countenance of the image.

After being forced to change the method from interview to survey, we made the effort to follow the same order of questions, disclosing as little as possible from the start. The opening page of the survey, implemented as a Google form, only had the title "A well-known statue", and provided the following information:

This study is about a particular statue that you are likely to recognise. We will ask about how you experience it, and what you know about it. It will take no more than 15 minutes to complete.

You will be anonymous, and the questions we ask at the end about your background are for statistical purposes only. By clicking below, you agree

- to participate in the study about "a well-known statue"

- not to discuss its contents with others who are about to participate in it, so they are not influenced

- that results may be presented in research reports or publications.

Thank you again for your participation!

In the first batch of questions, participants were shown the photography of Den lille Havfrue presented in Fig. 6, which we chose as it displays the whole body and face of the character, and asked: (\#1) if they recognized it; (\#2) if so, how; and (\#3) where it was located - all these questions indicative of the degree of familiarity with the statue. 


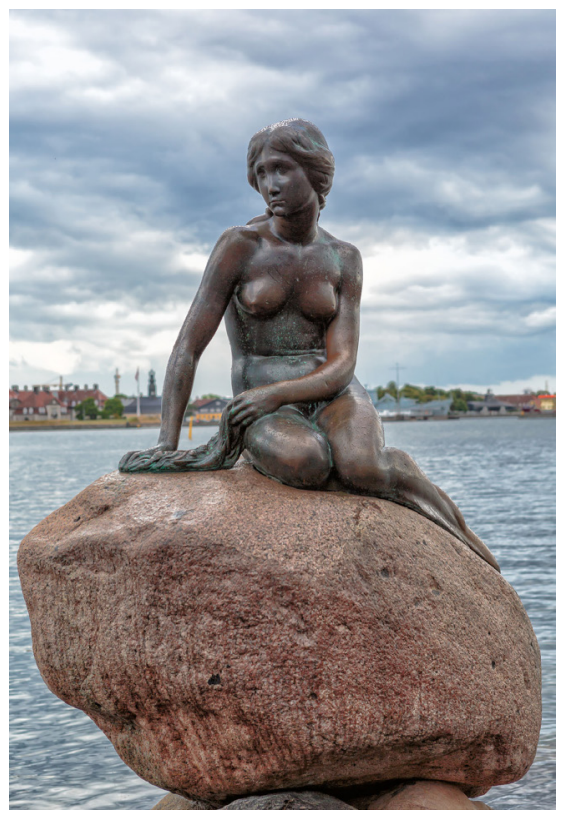

Figure 6. The photo of Eriksen's Den lille Havfrue shown to participants in the survey [photo from https://en.wikipedia.org/wiki/The_Little_Mermaid_(statue)]. Accessed on 10 July 2020.

The second page included the three key questions: (\#4) which character the statue represents; (\#5) what "feelings and thoughts it evokes in you"; and (\#6) the request "Please describe briefly the story about this character, or make one yourself. Don't forget to mention the ending of the story. (5-6 sentences would be enough)!”. The photograph was shown again during this step of the survery.

The third and final page asked (\#7) where they knew the story from, with (a) H. C. Andersen, (b) Disney and (c) "Other" given as non-exclusive alternatives in a multiple-choice question; (\#8) their first language; (\#9) their place of permanent residence; and (\#10) age. The information obtained from these questions was meant to serve as independent variables about prior knowledge and background.

The survey was distributed to Chinese and European participants living in Southern Sweden (note that we did not ask about their "nationality" and many of the second group indeed appeared not to be Swedish). This gave the opportunity to all participants to have seen the statue in real life, as this takes but an easy short train trip from Malmö to Copenhagen. The two groups were expected to display differences in their narrations due to differences in the cultural background knowledge, and possibly also in their interpretations of non-narrative aspects of the statue. 
Based on this research design, and the questions posed in the previous sections, we could formulate the following hypotheses:

1. Participants who were primarily familiar with Andersen's fairy tale would provide more narrations with tragic endings.

2. Participants who were primarily familiar with the Disney movie would provide more narrations with happy endings.

3. Participants who were not familiar with any prior story would not be able to narrate a story (or else would provide very idiosyncratic ones).

4. There would be culture-specific differences between the narrations of the two groups (Chinese vs. European), beyond the differences accountable by $(1-3)$.

As for responses to the question concerning what "feelings and thoughts it evokes in you", we had no prior hypothesis as to if this would depend on prior knowledge or cultural background, and considered the matter to be exploratory.

\section{Results}

The responses to the survey from 20 European and 19 Chinese participants that included answers to all questions were included in the analysis. 36 answered that they recognized the statue. 24 of these claimed to have seen it in real life, and the others in various visual representations. A total of 33 participants could answer the question which character it represented correctly, including terms like 'mermaid' and 'little mermaid', as well as 'daughter of the sea', which was considered correct, given that popular translations of Andersen's fairy tale into Chinese are called 海的女儿 ('Daughter of the sea'). ${ }^{8}$ Six participants could not name the statue (including three who had previously said they recognized it) and gave replies such as "a girl", "no idea" and "I am not sure, but a vulnerable sad-looking woman". These six participants were equally divided between the Chinese and European groups.

As can be seen from Table 1, the majority of the participants claimed familiarity with Andersen's fairy tale. Six knew the story from the Disney film, including two who stated that they also knew it from Andersen's original fairy tale. 12 participants either claimed not to know any story related to the statue, or (in a few cases) expressed a deliberate wish to invent their own. Finally, one participant

8 Published by Chinese National Publishing houses as 安徒生童话故事集 and by People's Literature Publishing House as 人民文学出版社, translated by Junjian Ye (叶君健), a famous translator who systematically translated Andersen's fairy tales into Chinese. Some of these are included in student textbooks and are widely known in China. 
(a native speaker of Danish) stated rather optimistically that the story belongs to "collective cultural consciousness".

Table 1. Prior knowledge of the story about the character represented in the photo in Fig. 6.

\begin{tabular}{|l|c|}
\hline Claimed knowledge of prior story & $\begin{array}{c}\text { No. of } \\
\text { participants } \\
\text { (total 39) }\end{array}$ \\
\hline Andersen's fairy tale & 20 \\
\hline Andersen's fairy tale and the Disney film & 2 \\
\hline The Disney film & 4 \\
\hline Does not know (or like) the original story & 12 \\
\hline $\begin{array}{l}\text { "I feel like the story is in the collective cultural consciousness, } \\
\text { like I know the broad strokes of the story" }\end{array}$ & 1 \\
\hline
\end{tabular}

To test Hypotheses 1-3, predicting different types of responses to the question that asked participants to narrate "the story about this character, or make one yourself" depending on prior knowledge, we classified the responses in five categories: narrations with TRAGIC endings, with HAPPY endings, with MIXED endings, with AMBIVALENT endings (where the character is transformed into a 'daughter of the air' or similar) and responses that were in fact NO STORIES. Examples (1) and (2) illustrate the category TRAGIC, with the first one following Andersen's fairy tale, while the latter departing from it substantially.

(1) The little mermaid wishes to live on land, as she is "in love with" the prince. She makes a deal with the "witch" who gives her legs and the ability to live on land, but takes her voice in return. I cannot remember how the love-story unfolds, but the story ends with the little mermaid turning into sea-foam.

(2) The Little mermaid lived in the ocean, but had always dreamt of being a human. One day she met a man and fell in love. Her fins kept her from walking on land and pursuing her love. She made a deal with the Devil and got legs, but she gave more than she thought. The Devil took her soul and now she forever walks the streets of Copenhagen soulless and restless.

The narration in (3) was classified as HAPPY, but it should be noted that the participant was clearly inventing their own story (with some apparent inspiration from "Rudolf the Red-Nosed Reindeer"). Example (4) shows a story with a MIXED ending, stating explicitly that the happy ending is based on "the Disney version". 
(3) She is swimming around in the sea and eats fish, mostly by herself because the other fish-humans bully her. She eats them raw, which at first seems rather unappetising and barbaric, but it is normal for a fish-human. One day, when she is sitting on the rock to get a nice tan on her scales, she sees the earth-humans eating broiled salmon. She wonders what it tastes like and longs for a more diverse diet. Most days of the week, you see, she only gets to eat herring. One day she steals salmon from the earth-humans to bring to her people in the depths of the sea. She becomes a hero and gets to be known as the salmonlady-with-the-tanned-scales. After that day, no one would make fun of her.

(4) She's a mermaid who falls in love with a human Prince. She gives her voice to a witch in exchange for legs so she can walk on land to meet the Prince. But she has to get him to fall in love with her within a specific number of days. When she fails, she turns into sea foam. (or succeeds and marries him, in the Disney version)

The narrations in (5) and (6) were categorized as AMBIVALENT, with (5) being in accordance with Andersen's fairy tale, while (6) is clearly an artistic invention. Neither is unambiguously happy or tragic.

(5) She was a mermaid that traded her nature to become human, because she fell in love with a prince. The relationship did not lead to marriage, as it was supposed to, and in order for her to save her life by being turned into a mermaid again, she has to kill the prince. Nevertheless, she couldn't do it, and then she was turned into a spirit that was bound to do good to others.

(6) The mermaid is keeping watch over her city, which lies by the sea. While she keeps watch, no irreparable harm may come to it. She knows that the city cares for her, and her domain, just as she cares for it. She has lost her human lover to the depths of the sea, but she will not lose her city. She sits and watches, waiting and hoping against hope for his return.

Finally, examples (7) and (8) illustrate the category NO STORY, where the response qualifies not as a story, but as a description, even if this could be quite imaginative as in (7), or possibly as only the beginning (but not middle and end) of a story as in (8).

(7) A woman that is taken advantage of in a working context (due to what I think is a rag or cloth in her hand). Towards the fact that she is depicted as a statue I get a feeling that she has done something extraordinary for human rights, women or (working) people generally.

(8) In the deepest spot of the sea was his castle. The walls were made of blur coral. On the roof were shells that opened and closed when the water passed by. And that is where the sea king lived with his mother and four daughters, each one born a year apart. The youngest of the four princesses was the little mermaid. 
Fig. 7 shows the distribution of these response categories in relation to claimed prior knowledge. As can be seen, Hypothesis 1 was clearly supported. Of the 20 participants who claimed familiarity only with Andersen's fairy tale, 15 produced narrations with TRAGIC, and three with AMBIVALENT endings. Hypothesis 2, on the other hand, was not supported, as of the four participants who claimed prior knowledge of the Disney film, two did not respond with a story, and two produced TRAGIC stories, both their own inventions, with example (2) being one of these. The participants who explicitly acknowledged both prior stories were the only ones to produce MIXED endings to their narrations, one of which is shown in (4). This indicates some influence of the Disney version of the story.

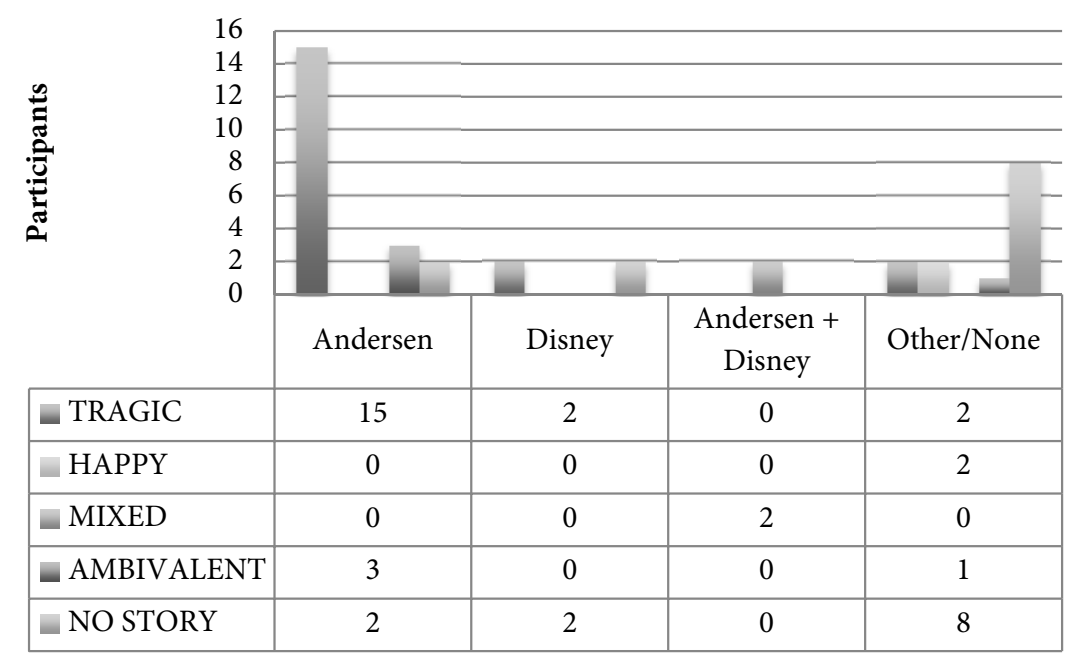

Figure 7. Type of response per participant, in relation to prior knowledge: Andersen's original tale, the Disney film, both, or other/no knowledge.

Most significant for our questions, however, was the strong support for Hypothesis 3: the participants that did not acknowledge any specific prior story, either did not produce any story at all, or tended to create "original" ones, like the HAPPY one in (3) and the AMBIVALENT one in (6). The pattern is clearly converse to that given on the left of the figure, where the narrations predictably followed Andersen's original fairy tale.

Concerning cultural differences, as predicted by Hypothesis 4, we can see a certain difference between the two groups, shown in Fig. 8. The Chinese participants either produced TRAGIC stories, with the protagonist transforming into 
"sea foam", or NO STORY, like the response in (8). The responses of the European group were, on the other hand, more varying, although, as for the Chinese group, the TRAGIC versions predominated.

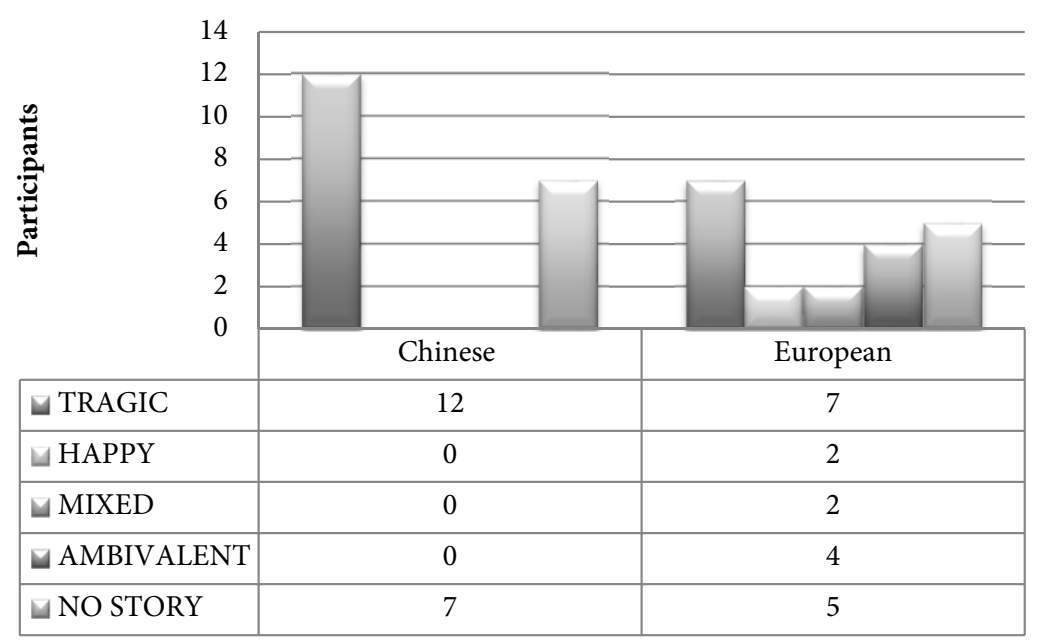

Figure 8. Comparing response types in the two cultural groups.

This difference correlates with a parallel difference in the responses on prior knowledge, as the Chinese group (at first sight, surprisingly!) claimed knowledge of the Andersen fairy tale more often than the European group and, conversely, the latter more often stated that they did not know (or like) Andersen's fairy tale. However, as noted, Andersen's story enjoys wide popularity in China, and has even entered primary school textbooks in an abridged translation, notably without the part about the mermaid being transformed into a spirit/angel for 300 years. Thus, it is hardly surprising that there were no AMBIVALENT endings suggested by the Chinese participants. Further, according to the reported age of the Chinese participants, we can suppose that many of them had read this story when they were in primary school in China. Even if they had seen the Disney film later, it is likely that they received their strongest impressions about 海的女儿, 'the daughter of the sea, in their early formative years. Or else, they had apparently forgotten the story, as many schoolchildren do, and thus had no story to tell when asked about it in the survey.

Finally, there seemed to be some cultural influence on the interpretation of the supposedly "non-narrative" features of the statue, the exploratory question that 
we stated at the end of Section 3. We categorized the responses to question (\#5) concerning "feelings and thoughts" evoked, in three types: 24 belonged to the type SADNESS, for responses that included terms like 'sad', and 'sorrow'; five to the type OTHER EMOTION, including terms like 'gentleness', 'upset'; and 12 to the type NO EMOTION, with responses like 'childhood' and 'beautiful woman'. Fig. 9 shows that the European participants were more consistent with replies of the type SADNESS, which notably does not match the pattern of their storytelling, shown in Fig. 8.

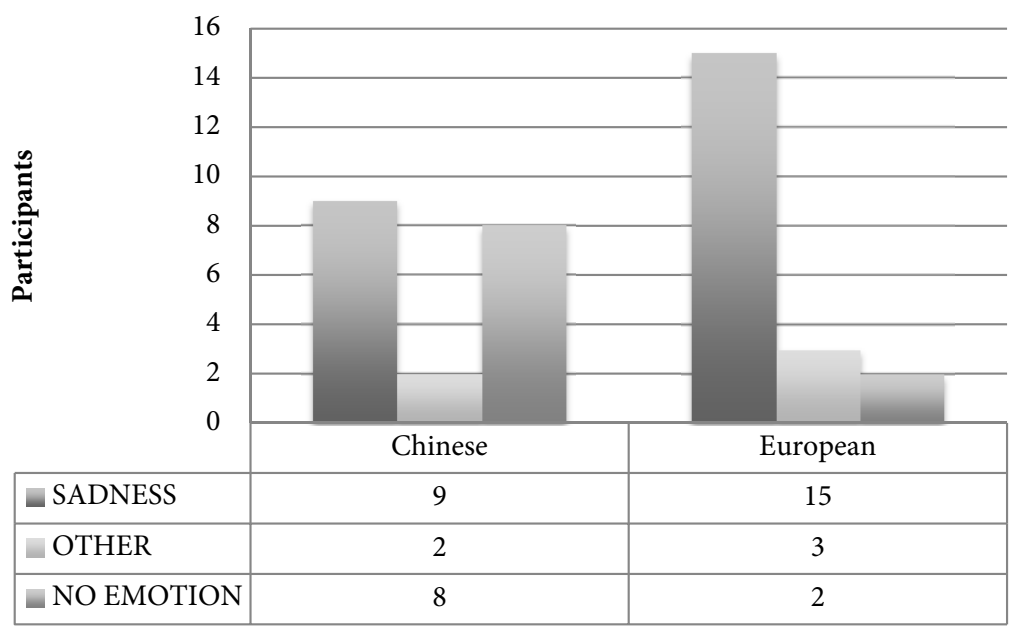

Figure 9. Comparing "evoked feelings and thoughts" in the two groups.

The replies of the Chinese participants, however, fell in a rather binary pattern of SADNESS/NO EMOTION, which does indeed resemble that in Fig. 8. Without being able to claim statistical significance due to the low number of participants, we can also see some signs of a correlation: of the NO-EMOTION responses, five belonged to participants who produced NO STORY (of seven in total, see Fig. 8). Conversely, seven of the nine SADNESS responses belonged to participants who had told TRAGIC stories (of the 12 in total). Thus, we cannot exclude some effect of the narrative on the perception of "non-narrative" features of the statue, especially when the audience has cultural knowledge that differs to a considerable degree from that of the author of the artwork, as it was in the present case. 


\section{Discussion}

The most important findings of the empirical study were the correlations between the type of prior knowledge that participants claimed concerning the character represented by the statue Den lille Havfrue, and the narrations they produced. Characteristically, those who acknowledged Andersen's fairy tale predominantly narrated "tragic" stories (and were the only group that produced stories of the "ambivalent" kind), while those who either explicitly did not acknowledge any prior story, or were vague about this, predominantly did not produce any story in response to the question. Interestingly, there were hardly any (unambiguously) "happy" stories produced by the participants, including those who claimed to know the prior story from the Disney film.

These results clearly support our preliminary conclusion based on theoretical analysis (see Section 2) that statues (like Den lille Havfrue) lack the potential for primary narrativity (P-Nar), but can nevertheless be part of a narrative through secondary narrativity (S-Nar). Following the ideas of Stampoulidis 2019, we could propose the formulas in (9-10) as "formalizations" of the key notions:

\section{S-Nar (Expression (e.g. statue), Prior Story, Setting) = Narration;}

P-Nar (Expression (e.g. verbal text), Narration, Setting) $=$ Story.

What (9) implies is that different viewers of the same statue (Expression) can interpret it in terms of different Narrations, given (a) differences in Prior Story, and (b) differences in cultural or frame Settings. S-Nar is thus a function, in the mathematical sense, which takes Expression, Prior Story and Setting as "input", and delivers Narration as "output". This also highlights the feature that there is close interaction between the three input terms. For example, all participants in our survey viewed the same Expression (though only some had seen it in reality), yet not only did they tell different stories about it, but at least the Chinese group appeared to be influenced by their prior stories (or lack of them) in interpreting the emotions that the statue expressed. A further clear reflection of the different Settings for the two groups of participants was that the Chinese participants were simply not familiar with the "original" ending of the story in which the protagonist becomes an angel. Since this apparently did not fit the canons of Chinese culture, it was not included in the translations of 海的女儿 that they had likely read as children.

On the other hand, the role of Prior Story is not all-powerful, as even those who were familiar with the "happy" version by Disney did not produce happy narrations, presumably since these would have been incongruent with what the 
statue expresses in bodily terms (see Fig. 6). In sum, different audiences would be likely to perform substantially different narrative (and to some degree, nonnarrative) interpretations of an expression such as a statue, based on their knowledge of prior stories and general cultural background, as statues can narrate only through secondary narrativity.

In contrast, as expressed in (10), a verbal text or a film can provide enough information to give the Narration itself as "input", and produce the Story as "output". Yet even here, (culture, frame) Setting is included in the equation to indicate the interaction between the terms, and to show that in effect there will be quite different "stories" (interpretations) given in different cultural and historical circumstances, as literary and film criticism clearly shows.

Are we justified in providing such a generalization on the basis of a single case study? We believe so, as these conclusions also cohere with those based on theoretical analysis as discussed in Section 2. In support of our proposal, we could once again quote Werner Wolf (2011: 510; our emphasis, W. L., J. Z.), who, more than many other scholars, has explored the potentials of pictures and sculptures (which is a broader category than statues) to narrate:

[...] for the purpose of narrativization sculpture must appeal as much if not more to the viewer's imagination than painting or photography, let alone verbal representations, and moreover that the narrativization of sculpture, as is the case with other visual media, may considerably depend on an intermedial reference to a verbal story.

However, we could also illustrate the power of secondary narrativity concerning statues, referring to the recent anti-racism ('Black Lives Matter') protests across the globe that were sparked by the killing of George Floyd by the police in the USA. In connection with the protests, many statutes have been defaced, vandalized and, often, removed. Table 2, based on the BBC article "George Floyd protests: The statues being defaced" from 10 June $2020,{ }^{9}$ shows examples of three such statues, and how they could be part of very different narratives, based on different Prior Stories and Settings. While one kind of these may justify the statues being erected in public space to begin with, the second one understandably motivates many to wish their removal.

9 https://www.bbc.co.uk/news/world-52963352 was accessed on 10 July 2020. 
Table 2. Different narrative interpretations of statues that have been defaced in Black Lives Matter (BLM) protests during June 2020, as illustrations of secondary narrativity.

\begin{tabular}{|l|l|l|}
\hline \multicolumn{1}{|c|}{ Statue } & \multicolumn{1}{|c|}{ Prior Story + Setting (1) } & \multicolumn{1}{c|}{ Prior Story + Setting (2) } \\
\hline $\begin{array}{l}\text { Edward Colston } \\
\text { (Bristol, UK) }\end{array}$ & $\begin{array}{l}\text { A successful merchant, and } \\
\text { benefactor of the city of Bristol. } \\
\text { "A great man who did great } \\
\text { things" }\end{array}$ & $\begin{array}{l}\text { His ships transported about 80,000 } \\
\text { men, women and children from } \\
\text { Africa to the Americas, and he } \\
\text { ordered the sick and the rebellious } \\
\text { to be thrown overboard. } \\
\text { "A slave trader and a murderer" }\end{array}$ \\
\hline $\begin{array}{l}\text { King Leopold } \\
\text { Belgium) }\end{array}$ & $\begin{array}{l}\text { One of the longest ruling } \\
\text { kings of Belgium (1865-1909), } \\
\text { reigning over a period of peace } \\
\text { and prosperity. }\end{array}$ & $\begin{array}{l}\text { Turned Congo into a "private } \\
\text { colony", and ruled most cruelly. } \\
\text { Responsible for the deaths of ca. } \\
\text { 10 million Congolese, placing } \\
\text { some in a human zoo in Belgium. }\end{array}$ \\
\hline $\begin{array}{l}\text { Robert E Lee } \\
\text { (Charlottesville } \\
\text { Virginia, USA) }\end{array}$ & $\begin{array}{l}\text { A great commander of the } \\
\text { Confederate Army in the US } \\
\text { Civil War (1861-1865). A } \\
\text { "symbol" of US history and } \\
\text { Southern culture. }\end{array}$ & $\begin{array}{l}\text { A commander of the pro-slavery } \\
\text { South. A slave owner, who } \\
\text { encouraged severe beatings of } \\
\text { those who tried to escape. }\end{array}$ \\
\hline
\end{tabular}

In sum, different viewers with different prior knowledge, as well as cultural and political convictions, will be led to very different interpretations when they look at the same statue, as an effect of secondary narrativity. Interestingly, even Eriksen's little statue, the object of many previous acts of defacement and vandalism, has recently been included in the anti-racism narrative (Fig. 10), leaving people perplexed, as stated in an article from the English-language Danish newspaper The Local: ${ }^{10}$

The meaning of the apparent racist accusation has however so far left some scratching their heads. "Of course, in general with literary works, you can read them with various glasses," Ane Grum-Schwensen, an expert employed by the H. C. Andersen centre at the University of Southern Denmark, told broadcaster TV2. "However, I do find it a little difficult to see, what would be especially racist in the adventure 'The Little Mermaid"' she added.

10 https://www.thelocal.dk/20200703/racist-fish-little-mermaid-statue-vandalised-incopenhagen was accessed on 10 July 2020. 


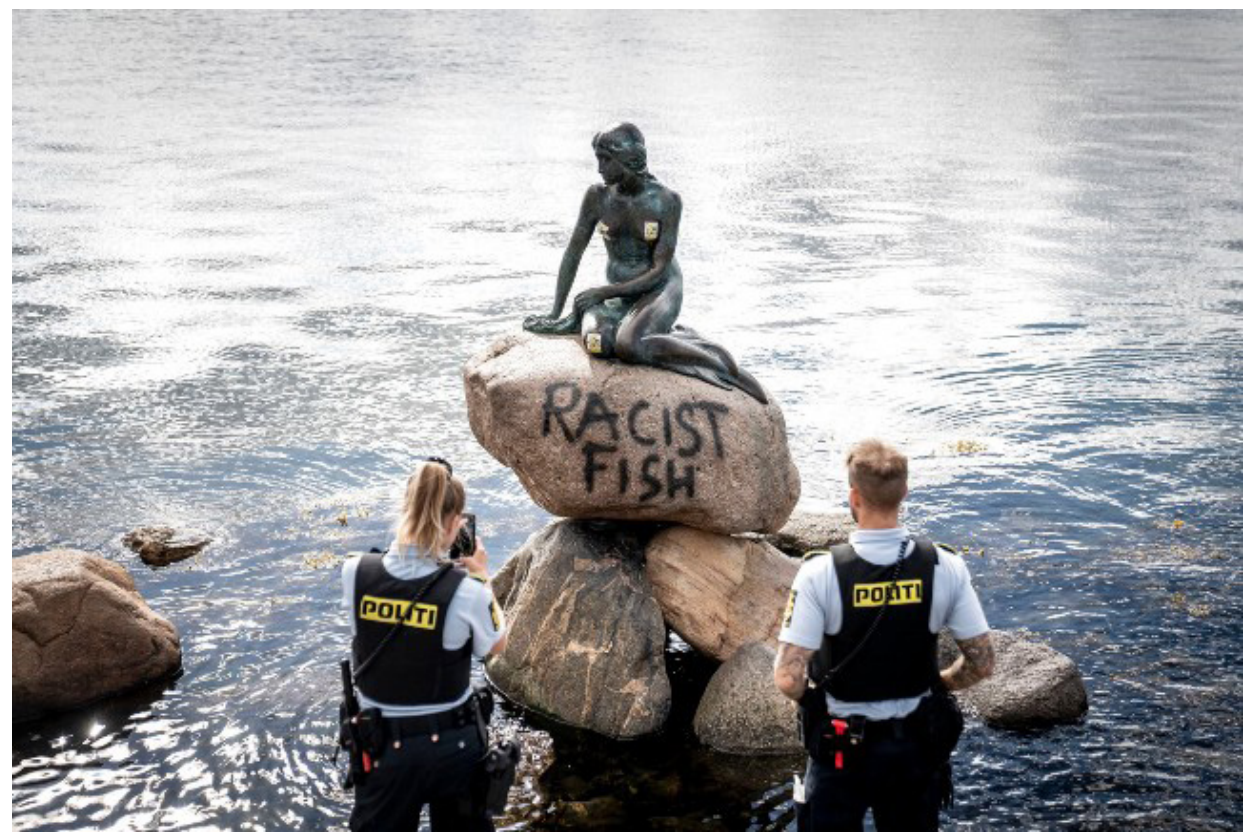

Figure 10. A recent interpretation of Den lille Havfrue, under the influence of the current Setting, from https://www.thelocal.dk/20200703/racist-fish-little-mermaid-statue-vandalisedin-copenhagen, accessed on 10 July 2020.

It its characteristic that the cited "expert employed by the H. C. Andersen centre" looks for and fails to find racist content in Andersen's fairy tale, but it is unlikely that it was the Prior Story that motivated this particular act of protest. At least on the face of it, it is more likely that the Disney film, with its associations to US capitalism, or even associations of the statue with the Carlsberg brewery, whose owner commissioned the statue as mentioned in the introduction, were part of the Setting that provoked this defamation. Or it could even have been an exaggerated ironic response to the re-interpretations of statues by the protest movement of the 2020. In any case, a "racist" interpretation could only be the product of secondary narrativity, which is the only way in which statues can narrate.

Finally, we may consider in this context the theoretical question that we posed at the onset: if sculptures in general, and statues in particular, can be considered the outcome of intersemiotic translation. In Section 2 we concluded that we could answer it affirmatively, but only if we dispense with Nida's (2004) requirement for dynamic equivalence between source and target texts, requiring that the two texts lead to "similar reactions" in their respective audiences. This condition may be 
applicable to messages that display primary narrativity, and, even then, only to a degree. Andersen's fairy tale and the Disney film are both polysemiotic messages that "tell" a Story on the basis of polysemiotic Expressions and Narrations, as shown in (10), and hence realize primary narrativity. However, while the Disney film is clearly an intersemiotic translation of the fairy tale, it differs from the latter so much in both expression and content that no equivalence can be expected there. Thus, Nida's concept is only applicable to inter-lingual, and not intersemiotic translation.

\section{Conclusions}

In this article we have explored the concepts of intersemiotic translation (Jakobson 1959) and secondary narrativity (Stampoulidis 2019) through a case study of the well-known statue Den lille Havfrue ('the little mermaid') in Copenhagen. With the help of cognitive semiotics and its "conceptual-empirical loop" we could both explicate the original concepts to a greater extent, and corroborate theoretical claims with the help of empirical findings. Here, we summarize these and conclude by providing answers to the questions asked at the end of the introduction.

Can statues such as Eriksen's Den lille Havfrue be regarded as the outcome of a process of intersemiotic translation, given that the target is so semiotically reduced compared to the source? Our answer to this question is affirmative, but only if requirements from translation theory for "equivalence" between source and target messages are abandoned; such requirements may be applicable to translations of verbal texts (both within and between languages), but not to intersemiotic translation, which necessarily involves some difference in source and target semiotic systems (language, gesture, depiction, music, dance, sculpture...), and thus various degrees of non-equivalence in content.

Are statues such as Den lille Havfrue narratives? With the help of the concepts of primary and secondary narrativity, we could answer this with both 'No' and 'Yes'. Statues (and single static pictures) do not provide sufficient information to express narration on the basis of which to understand a whole story, and thus lack the capacity for primary narrativity, in contrast with narrative texts in language or (complex) semiotic systems such as film. At the same time, when combined with prior stories and conditioned by socio-cultural settings, statues can very well be considered as expressions that give rise to narrations, and thus constitute part of the overall narrative. These narratives will differ extensively, however, depending on precisely which prior stories and settings are involved. 
Will viewers of statues interpret even "non-narrative" aspects through the filter of their (different) prior stories? The "filter" metaphor is to some extent misleading, suggesting exaggerated claims about linguistic determinism over cognition, while linguistic influence is a position that is much more easily supported conceptually and empirically (Zlatev, Blomberg 2015). In our study, we found that even participants who operated with a "happy" prior story about "the little mermaid" did not narrate correspondingly happy stories when asked, and did not describe the emotions expressed through the sculpture's face and posture as "happy". At the same time, participants who lacked any prior story, and in particular those from a substantially different culture, seemed less prone to describe the statue as expressing "sadness". Hence, we can describe the relation between (a) the statue itself, (b) the relevant prior story, and (c) the cultural background, as forming a cycle of interaction, with narrative interpretations emerging from this whole cycle. This is why we have placed the term "nonnarrative" in scare quotes in the question above: it is hard to decide a priori which aspects are "narrative" and which are not, once the interpretive cycle has begun.

Can we hope to generalize aspects of the analysis to (some classes of) sculptures, as a particular kind of semiotic system? We can, given that the empirically grounded theoretical analysis in the previous answers holds true. Of course, some sculptures will be much more expressive and "dynamic" than Den lille Havfrue, e.g. the famous Laokoon mentioned in Section 2, or such masterpieces as Rodin's Gates of Hell ${ }^{11}$ which can "tell" not one but hundreds of stories as the viewer stands mesmerized before them. Still, as with the humble "little mermaid", these stories will be extremely dependent on what one brings along to the interpretative cycle in terms of both cultural and personal experience. This is why statues, which are long-lasting public representations in several senses of the term, will always be highly sensitive, and even contentious, evoking extremely different interpretations in different historical epochs, and different people. The "racist" interpretation of the poor little mermaid shown in Fig. 10 graphically illustrates this. ${ }^{12}$

11 https://en.wikipedia.org/wiki/The_Gates_of_Hell was accessed on 10 July 2020.

12 We warmly thank Georgios Stampoulidis for comments on a previous draft of this paper. We also thank Göran Sonesson and other participants in the Cognitive Semiotics "zoom seminar" on 14 May 2020 for their questions and the following discussion, as well as the two anonymous reviewers and the editor of the journal for many helpful comments. The research on this paper is supported by the Major Project of National Social Science Fund of China "Research on Discursive Construction, Translation and Communication of Major-country Diplomacy with Chinese Characteristics"(No. 17ZDA318), (Ministry of Education in China) Project of Humanities and Social Sciences (教育部人文社会科学研究青年项目资助 No. 20YJC740024), and (Henan Province in China) Project of Humanities and Social Sciences (2018年度河南省哲学社会科学规划项目No. 2018CYY032). 


\section{References}

Allen, Richard J. 2013. Beginning, middle, end of an era: Has technology trumped Aristotle? Journal of Film and Video 65(1/2): 9-29. https://doi.org/10.5406/jfilmvideo. 65.1-2.0009

Aristotle 1812[335 BC]. Treatise on Poetry. London: Luke Hansard \& Sons.

Bal, Mieke 1997. Narratology: Introduction to the Theory of Narrative. Toronto: University of Toronto Press.

Bennett, Karen 2007. Words into movement: The ballet as intersemiotic translation. In: Brilhante, Maria João; Carvalho, Manuela (eds.), Teatro e Tradução: Palcos de Encontro. Lisbon: Colibri, 125-138.

Bom, Anne K. 2012. When heritage tourism goes glocal: The Little Mermaid in Shanghai. Journal of Heritage Tourism 7(4): 341-357. https://doi.org/10.1080/1743873X.2012. 722641

Branigan, Edward 1992. Narrative Comprehension and Film. London: Routledge.

Budniakiewicz, Therese 1998. Narrative structures. In: Bouissac, Paul (ed.), Encyclopedia of Semiotics. New York: Oxford University Press, 437-443.

Desogus, Paolo 2012. The encyclopedia in Umberto Eco's semiotics. Semiotica 192(1/4): 501-521. https://doi.org/10.1515/sem-2012-0068

Diget, Ida Stevia Krogh 2019. Intersemiotic translation from film to audio description: A cognitive semiotic approach. (MA thesis.) Lund: Lund University.

Genette, Gérard 1980. Narrative Discourse: An Essay in Method. Ithaca, New York: Cornell University Press.

Halliday, Michael Alexander Kirkwood 2001. Towards a theory of good translation. In: Steiner, Erich; Yallop, Colin (eds.), Exploring Translation and Multilingual Text Production: Beyond Content. Berlin: Mouton de Gruyter, 13-18.

Holsanova, Jana 2016. A cognitive approach to audio description. In: Matamala, Anna; Orero, Pilar (eds.), Researching Audio Description. Basinstoke: Palgrave, 49-73. https:// doi.org/10.1057/978-1-137-56917-2_4

Jakobson, Roman 1959. On linguistic aspects of translation. In: Brower, Reuben Arthur (ed.), On Translation. Cambridge: Harvard University Press, 232-239. https://doi. org/10.4159/harvard.9780674731615.c18

Jensen, Klaus Bruhn 2016. Intermediality. In: Jensen, Klaus Bruhn; Craig, Robert T. (eds.), The International Encyclopedia of Communication. London: John Wiley, 1-12.

Louhema, Karoliina; Zlatev, Jordan; Graziano, Maria; Weijer, Joost van de 2019. Translating from monosemiotic to polysemiotic narratives: A study of Finnish speech and gestures. Sign Systems Studies 47(3/4): 480-525. https://doi.org/10.12697/SSS.2019. 47.3-4.07

Mortensen, Finn H. 2008. The little mermaid: Icon and disneyfication. Scandinavian Studies 80(4): 437-454.

Nida, Eugene A. 2004. Toward a Science of Translation. Shanghai: Shanghai Foreign Language Education Press.

20YJC740024), and (Henan Province in China) Project of Humanities and Social Sciences (2018年度河南省哲学社会科学规划项目No. 2018CYY032). 
Nida, Eugene A.; Taber, Charles R. 2004. The Theory and Practice of Translation. Shanghai: Shanghai Foreign Language Education Press.

Pier, John 2008. After this, therefore because of this. In: Pier, John; Garcia Landa, José Angel (eds.), Theorizing Narrativity. Berlin: De Gruyter, 109-140. https://doi.org/10. 1515/9783110969801

Prince, Gerald 1982. Narratology: The Form and Functioning of Narrative. Berlin: De Gruyter. https://doi.org/10.1515/9783110838626

Prince, Gerald 2008. Narrativehood, narrativeness, narrativity, narratability. In: Pier, John; Garcia Landa, José Angel (eds.), Theorizing Narrativity. Berlin: De Gruyter, 19-27.

Queiroz, João; Atã, Pedro 2019. Intersemiotic translation, cognitive artefact, and creativity. Adaptation 12(3): 298-314. https://doi.org/10.1093/adaptation/apz001

Sonesson, Göran 1997. Mute narratives: New issues in the study of pictorial texts. In: Lagerroth, Ulla Britta; Lund, Hans; Hedling, Erik (eds.), Interart Poetics: Essays on the Interrelations of the Arts and Media. Amsterdam, Atlanta: Rodopi, 243-251.

Sonesson, Göran 2014. Translation and other acts of meaning: In between cognitive semiotics and semiotics of culture. Cognitive Semiotics 7(2): 249-280. https://doi. org/10.1515/cogsem-2014-0016

Stampoulidis, Georgios 2019. Stories of resistance in Greek street art: A cognitivesemiotic approach. Public Journal of Semiotics 8(2): 29-48. https://doi.org/10.37693/ pjos.2018.8.19872

Todorov, Tzvetan 1969. Structural analysis of narrative. NOVEL: A Forum on Fiction 3(1): 70-76. https://doi.org/10.2307/1345003

Wolf, Werner 2011. Narratology and media(lity): The transmedial expansion of a literary discipline and possible consequences, In: Olson, Greta (ed.), Current Trends in Narratology. Berlin: De Gruyter, 501-532. https://doi.org/10.1515/9783110255003.145

Zlatev, Jordan 2015. Cognitive semiotics. In: Trifonas, Peter Pericles (ed.), International Handbook of Semiotics. Springer: Dordrecht, 1043-1067. https://doi.org/10.1007/97894-017-9404-6_47

Zlatev, Jordan 2019. Mimesis theory, learning and polysemiotic communication. In: Peters, Michael (ed.), Encylcopedia of Educational Philosophy and Theory. Dordrecht: Springer. https://doi.org/10.1007/978-981-287-532-7_672-1

Zlatev, Jordan; Blomberg, Johan 2015. Language may indeed influence thought. Frontiers in Psychology 1631. https://doi.org/10.3389/fpsyg.2015.01631

Zlatev, Jordan; Sonesson, Göran; Konderak, Piotr (eds.) 2016. Meaning, Mind and Communication: Explorations in Cognitive Semiotics. Berlin: Peter Lang. https://doi.org/ 10.3726/978-3-653-04948-0

Zlatev, Jordan; Zywiczynski, Przemyslaw; Wacewicz, Slawomir 2020. Pantomime as the original human-specific communicative system. Journal of Language Evolution 5(2): 156-174. https://doi.org/10.1093/jole/lzaa006 


\section{Интерсемиотический перевод из сказки в скульптуру: исследование вторичной нарративности}

Мы представляем когнитивное семиотическое исследование нарративного потенциала статуи Den lille Havfrue («Русалочка») Эдварда Эриксена в Копенгагене. Основываясь на теоретическом анализе и опросе, в котором участвовали 20 европейских и 19 китайских респондентов, мы утверждаем, что эта и подобные статуи могут рассматриваться как продукты интерсемиотического перевода, если мы откажемся от каких-либо требований «эквивалентности» между исходным текстом и целевым текстом, так как статуи обязательно семиотически сильно редуцированы. В то время как исходные повествования представляют собой случаи первичного повествования, рассказывая аудитории истории, статуи участвуют лишь во вторичном повествовании, где предшествующая история необходима для того, чтобы статуя воспринималась как повествование. В нашем исследовании это нашло отражение в корреляции между сообщениями о ранее накопленных знаниях и нарративными (и, возможно, даже не нарративными) толкованиями Den lille Havfrue. В итоге мы соотносим дискуссию с современным культурным и политическим контекстом, в котором многие статуи, включая Den lille Havfrue, стали частью глобального антирасистского нарратива.

\section{Intersemiootiline tõlge muinasjutust skulptuuriks: teisese narratiivsuse uurimine}

Tutvustame kognitiivsemiootilist juhtumiuuringut, mis keskendub Edvard Erikseni Kopenhaagenis asuva kuju „Väike merineitsi“ narratiivsele potentsiaalile. Lähtuvalt teoreetilisest analüüsist ning küsitlusest, milles 20 Euroopa ja 19 Hiina päritolu osalejat vastasid skulptuuri puudutavatele küsimustele, väidame, et nii seda kui ka teisi samasuguseid kujusid võib pidada intersemiootilise tõlke tulemiks, kuid üksnes juhul, kui loobume allika ja tulemi vahelise „ekvivalentsuse“ nõudest, sest kujud on semiootiliselt paratamatult tugevasti redutseeritud. Kui alliknarratiivide puhul on tegemist esmase narratiivsuse juhtumitega, mille puhul jutustamine pakub publikule lugusid, siis kujud osalevad üksnes teiseses narratiivsuses, mille puhul selleks, et mõista kuju jutustamisena, osutub vajalikuks varasem lugu. Meie uurimuses peegeldus see korrelatsioonides osalejate varasemate teadmiste ning „Väikese merineitsi“ narratiivsete (ja võimalik ka, et mittenarratiivsete) tõlgenduste vahel. Lõpuks seome arutelu tänapäevase poliitilise ja kultuurilise taustaga, kus mitmed kujud, sealhulgas „Väike merineitsi“, on saanud osaks globaalsest antirassistlikust narratiivist. 